\title{
When the Face Becomes a Carrier: Biopower, Levinas's Ethics, and Contagion
}

\author{
SARAH HORTON *
}

\begin{abstract}
In the midst of a pandemic, what does it mean to see the Other as Other and not as a carrier of the virus? I argue that in seeking a Levinasian response to the pandemic, we must be mindful of the implications of the mechanisms of surveillance and control that, presented as ways to protect the Other, operate by controlling the Other and rendering our relation to the Other increasingly impersonal. Subjected to these mechanisms, the Other becomes a dangerous entity that must be controlled, and the state that deploys them comes increasingly to mediate the relation between self and Other. The more we rely on such mechanisms for protection, the easier it becomes to regard the Other not as one who summons me to an infinite responsibility but as a vector of disease. Despite : II f fferences between Levinas's and Foucault's approaches, reading them in conversation she hat the control and surveillance of the population functions within a discourse that medicalizes and objectifies the Other in favor of the centralizing power that uses those technologies. In defiance of Levinas's warning against imposing a narrative on the Other's suffering, this discourse coopts that suffering as a justification for biopower.
\end{abstract}

Keywords: biopower, Covid-19, disease, ethics, Foucault, Levinas, SARS-CoV-2, surveillance.

\section{Introduction}

I argue that when evaluating responses to the Covid-19 pandemic in light of Emmanuel Levinas's ethics, we must be aware that the technologies and procedures that are presented as ways to protect us all - including contact tracing, smartphone tracking apps, mask mandates, quarantines, lockdowns, enforced social distancing, and vaccine passports - in fact operate by absorbing the Other into a population that must be controlled and by rendering the relation to the Other increasingly impersonal. The state that deploys these methods in the name of fighting the pandemic comes increasingly to mediate the relation between self and Other, and such technologies and procedures teach us to regard the Other not as one

\footnotetext{
* Boston College, USA.

$\triangle$ hortonsc@bc.edu

(iD) https://orcid.org/
} 
who summons me to an infinite responsibility but as a vector of disease. Subjected to these mechanisms that are ostensibly meant to provide security, the Other disappears and is replaced by a faceless, dangerous entity. Despite the differences between Levinas's and Michel Foucault's approaches, reading Foucault's Security, Territory, Population in conversation with certain Levinasian texts, particularly "Useless Suffering," shows that these mechanisms function within a discourse that erases the Other in favor of the centralizing state that deploys those mechanisms.

The stated goal of the mechanisms of control and surveillance that many countries have instituted is to protect people against an invisible enemy, Covid-19, that endangers everyone. Certainly transmissible diseases make clear our interconnectedness: I am not in fact a solitary ego but am fundamentally part of a community, whether I like it or not. Thus it might seem that Levinasian ethics requires us to adopt these mechanisms in order to protect the Other from disease. If I am, as Levinas writes, a hostage for the Other, am I not obliged to give up my freedom for the Other's sake? One can, however, invert the question: lockdowns and the mechanisms used to enforce them come with costs of their own (consider the impact of business closures on people's livelihoods, the impact of isolation on mental health, and the privacy risks of contact tracing, tracking apps, and vaccine passports), so dare I compel the Other to accept those costs if his or her values differ from mine? With the debate over the acceptability of surveillance and control seemingly undecided on the ethical plane, that debate then becomes a matter of politics: one tries to interpret empirical data about the dangers posed by the virus, by lockdowns, and by surveillance technologies, and then one weighs the costs and benefits of various courses of action to determine the extent to which it is permissible or advisable to surveil and control a population in an attempt to end or slow the pandemic. In short, we are faced with the classic debate over security versus freedom. What these political costbenefit calculations overlook, however, is that no matter how well-intentioned the individuals who institute and enforce it may be, the control of populations obscures the face of the Other. When one understands how these mechanisms of control operate, I argue, it becomes clear that they are themselves anti-ethical. I propose, therefore, to transcend the debate over the proper trade-offs between security and freedom by showing how the control and surveillance of the population breaks down the ethical relation to the Other. Although my argument will have broader implications for our understanding of the state, as will become particularly clear 
in the concluding section, my primary focus will be the mechanisms of control and surveillance employed in response to Covid-19.

\section{Understanding State Responses to Covid-19 as Exercises of Biopower}

To understand how the surveillance and control with which many governments have responded to Covid-19 is an exercise of biopower, let us begin by considering Foucault's presentation of biopower, at the beginning of Security, Territory, Population, as

the set of mechanisms through which what constitutes the fundamental biological features of the human species entered into the world of politics, into a political strategy, or, in other words, how society, modern Western societies, starting from the eighteenth century, took into account the fundamental biological fact that the human being constitutes a human species. ${ }^{1}$

Biopower, then, refers to the socio-political systems that take the human species understood as a biological category, rather than the individual, as the object on which they act. The mechanisms of biopower could emerge as such only when statistical analysis and the science of biology came to appear as the proper lenses through which to understand humans. Under the biopolitical regime, the human being is defined strictly as a member of a biological species that is to be subject to surveillance ${ }^{2}$ and control for

1. Michel Foucault, Sécurité, territoire, population: Cours au Collège de France, 1977-1978 (Paris: Seuil/Gallimard, 2004), 3, hereafter STP (Fr); Security, Territory, Population: Lectures at the Collège de France, 1977-1978, trans. Graham Burchell (New York: Palgrave Macmillan, 2007), 1, hereafter STP (En), translation modified.

2. It is necessary to briefly clarify the concept of surveillance and its place within the biopolitical regime, since Foucault distinguishes between the apparatus [dispositif] of security that operates on the population and the disciplinary mechanisms that deal with the correction of individuals, and he associates surveillance with the latter. Discipline, for Foucault, involves "detective, medical, and psychological techniques [...] which fall within the domain of surveillance, diagnosis, and the possible transformation of individuals" (STP [Fr], 7; STP [En], 5). Surveillance, then, is concerned with humans who may be disciplined and shaped as individuals. In contrast, the apparatus of security serves fundamentally not to normalize individuals but to see to the health and security of the overall population. It does not follow, however, that surveillance and other techniques of normalization cease once humans come to be understood as members of a biological species. On the contrary, Foucault explicitly states that disciplinary mechanisms support the mechanisms of security, which themselves predate the contemporary concept of the species: he writes that "in order actually to 
the sake of the population. After all, it is the population and not the individual that modern, statistically based science takes as its object - and so if this science does indeed offer the most proper and fundamental understanding of human beings, then humans are best governed by attending not to the training of individuals but to the regulation of the population as a whole. Crucially, the population is not even the sum of individuals considered in their individuality; on the contrary, "[the multiplicity of individuals] is pertinant simply as the instrument, relay, or condition for obtaining something at the level of the population." 3 There is no room here for the Other to and for whom I am infinitely responsible, with a responsibility that I cannot transfer to anyone else; it is not even a matter of the political justice in which I compare the interests of the Other and the third party. ${ }^{4}$ While justice does, for Levinas, oblige me to weigh the interests of different people, the ethical obligation remains fundamental: it is because the third is also an Other to and for whom I am infinitely responsible that I find myself responsible to and for multiple Others who may be in conflict. Biopolitics, in contrast, takes its calculations as fundamental, and so it cannot reckon with my infinite, incalculable responsibility. From the perspective of biopower, the Other, the third, and the self disappear into the population - a point the following section and the conclusion will

guarantee this security one has to appeal, to take just one example, to a whole series of techniques for the surveillance of individuals, the diagnosis of what they are, the classification of their mental structure, of their specific pathology, and so on; in short one has to appeal to a whole disciplinary series that proliferates under mechanisms of security and is necessary to make them work" (STP [Fr], 9-10; STP, [En], 7-8). Surveillance thus has its place within the biopolitical regime: individuals are surveilled so that the security of the population may be better assured. Moreover, surveillance has no regard for the face of the Other even within a primarily disciplinary regime, as the goal of disciplinary mechanisms is not to care for the Other but to bring each person into line with the norm. Certainly, one may attempt to justify surveillance by saying that it is best for each person to be thus brought in line, but as this article will show, surveillance functions by obscuring the face of the Other even when those who practice it claim or believe that surveillance is in people's best interest.

3. Foucault, STP (Fr), 44; STP (En), 42, translation modified.

4. See Levinas's observation, in "Philosophy, Justice, and Love," that "it is always starting out from the Face, from the responsibility for the other that justice appears, which calls for judgment and comparison, a comparison of what is in principle incomparable, for every being is unique; every other is unique" (Emmanuel Levinas, Entre nous: Essais sur le penser-à-l'autre [Paris: Grasset, 2016], 114, hereafter ENE; Entre Nous: On Thinking of the Other, trans. Michael B. Smith and Barbara Harshav [New York: Columbia University Press, 1998], 104, hereafter ENT). 
further develop. Biopower operates on the individual only accidentally: its real object is the population.

When considering biopower in general and state responses to Covid-19 specifically, it is essential to realize that biopower is not an abberation or a deviation from what we take to be the state's ordinary, everyday way of functioning. Thus it is not the case that only recognizable abuses of state power, such as clear violations of a state's constitution, are biopolitical. The apparatus [dispositif] of security, which takes the population as its object, is an operation of biopower whether it is understood as legitimate or illegitimate, as constitutional or unconstitutional. Even state decisions that may initially seem to be refusals to exercise power are operations of biopower: insofar as the contemporary state is a biopolitical one, both its actions and its inactions take place as biopower. For instance, the Swedish strategy is as much an exercise of biopower as full lockdowns and obligatory smartphone tracking, not only because Sweden has imposed certain restrictions (including the closing of high schools and universities, social distancing guidelines, limits on the number of people who may gather together, and the closing of restaurants and bars that violate these rules) but also, and more fundamentally, because the Swedish approach, like that of other nation-states, takes for granted that it falls to the governing power to devise a strategy for responding to Covid-19 that will produce the most satisfactory results for the population considered as an object of statistical analysis. The United Kingdom cited expert recommendations to justify its shift from a herd immunity approach to a lockdown; ${ }^{5}$ likewise, the Swedish government cited expert recommendations to support its decision to not lock down. Indeed, the Swedish strategy was developed by the official state epidemiologist, Anders Tegnell - who, what is more, has acknowledged that Sweden's approach is not fundamentally different from that of other countries, stating, "To say Sweden acted very different [sic] than other countries, that's not true. We did basically the same as many other countries. We did it in a slightly different way." ${ }^{\prime 6}$ Indeed. What

5. See Mark Landler and Stephen Castle, "Behind the Virus Report that Jarred the U.S. and the U.K. to Action," The New York Times, March 17, 2020, updated April 2, 2020 , https://www.nytimes.com/2020/03/17/world/europe/coronavirus-imperial-collegejohnson.html.

6. Quoted in Teri Schulz, "Do Sweden's COVID liberties cost lives?" Deutsche Welle, April 21, 2021, https://www.dw.com/en/do-swedens-covid-liberties-cost-lives/a-57268022. The article goes on to say that "[Tegnell] suggests that what Sweden has tried to do, in contrast with other countries, is to pinpoint 'what we need to close down where we have the effects so we don't have to close down the whole society.' The Swedish 
is at stake, in these different responses to Covid-19, are differing interpretations of the data, while the implicit claim that the data call for a response by the governing state power is undisputed and scarcely acknowledged. In Sweden as in the U.K., Norway, Denmark, and other countries that locked down, the state has assumed the authority to determine how best to manage the population in an attempt to ensure its health - physical, mental, and economic.

Indeed, ensuring the health of the population is the great aim of the biopolitical regime. In "The Politics of Health in the Eighteenth Century," Foucault observes that in the $18^{\text {th }}$ century we see "the emergence of the health and physical well-being of the population in general as one of the essential objectives of political power. [...] The imperative of health - at once the duty of each and the objective of all." 7 Unsurprisingly, then, the biopolitical state takes a considerable interest in epidemics - and as we will see over the course of this article, epidemics are not an exception to that state's standard operations, for biopower treats the population itself as an epidemic. It was also in the $18^{\text {th }}$ century, as Foucault explains in Security, Territory, Population, that epidemics came to be understood for the first time in terms of statistical analysis and of calculations of risk for different sectors of the population; ${ }^{8}$ for the first time as well the increase, through contagion, in the number of cases of a disease came to be understood as a crisis that "can only be checked either by a higher, natural mechanism, or by an artificial mechanism." 9 These analyses and interventions are understood to be the business of a centralized power, and so the management of epidemics, as well as the managing of famines, contributes to "the integration of the town within central mechanisms of power, or better, the inversion that made the town the primary problem,

government only has a temporary legal right to impose a lockdown if it deems it necessary - something it has not done" (ibid.). The basic principle that the governing power should consult experts to determine what sectors of society ought to shut down, and that it should then shut those sectors down, is, however, as well established in Sweden as it is elsewhere. It is true that the Swedish state faces, in this regard, greater constitutional restrictions than other states do, but the principle that the state must respond to Covid-19 remains.

7. Michel Foucault, "La politique de la santé au XVIII e siècle," in Dits et écrits, 1954-1988, vol. 3, 1976-1979, ed. Daniel Defert and François Ewald with Jacques Lagrange (Paris: Gallimard, 1994), 16; "The Politics of Health in the Eighteenth Century," trans. Robert Hurley, in The Essential Works of Foucault, 1954-1988, vol. 3, Power, ed. James D. Faubion (New York: The New Press, 2001), 94.

8. Foucault, STP (Fr); 62-63; STP (En), 60-61.

9. Foucault, STP (Fr), 63; STP, (En), 61. 
even before the problem of the territory." ${ }^{10}$ The enemy is not only external, nor is the enemy only some definite internal group; rather, the population as a whole is understood as a danger to itself. The population must be controlled so that it can be protected from itself. Certainly, this emphasis on the population itself as dangerous may and often does coexist alongside the exclusion of foreigners or of particular subgroups of the population. Consider, for instance, the attempt to force international students to leave the United States if their universities opted for online-only classes (a policy that was ultimately rescinded, without being implemented, when Harvard University and the Massachusetts Institute of Technology filed a lawsuit to overturn it). ${ }^{11}$ The population, then, is understood to be threatened both by those who are perceived as outsiders and by itself as a whole.

In the biopolitical state, the exclusion of foreigners, the oppression of particular groups of citizens, and the control of the entire population are all presented as ways to secure the population from supposed threats rather than as ways to preserve the ruler's sovereignty. The "problem" at hand is

no longer that of fixing and demarcating the territory, but of allowing circulations to take place, of controlling them, sifting the good and the bad, ensuring that things are always in movement, constantly moving around, continually going from one point to another, but in such a way that the inherent dangers of this circulation are anulled. No longer the safety (sûreté) of the Prince and his territory, but the security (sécurité) of the population and, consequently, of those who govern it. ${ }^{12}$

Here Foucault could have been describing $21^{\text {st }}$-century governmental responses to the Covid-19 pandemic. The aim of these responses is precisely to control the circulation of people to eliminate "the inherent dangers of this circulation." Lockdowns and quarantines restrict circulation with the promise that only in this way can circulation be made safe again at some indeterminate future moment. Contact tracing and tracking apps monitor circulation on the grounds that such monitoring is necessary to reduce the dangers of circulation to an acceptable level; again, the length of time during which such techniques will be necessary is unspecified,

10. Foucault, STP (Fr), 66; STP, (En), 64.

11. See Elizabeth Redden, "Government Rescinds International Student Policy," Inside Higher Ed, July 15, 2020, https://www.insidehighered.com/news/2020/07/15/ trump-administration-drops-directive-international-students-and-online-courses.

12. Foucault, STP (Fr), 67; STP (En), 65, translation modified. 
and it is often unclear what level of risk is deemed acceptable. It is true that some lockdowns have been announced for a specific period of time and have indeed been lifted at the end of that period of time: to take one example, the recent lockdown of Perth and Peel in Western Australia was set for three days - from 12:01 am, April 24, 2021 to 12:01 am, April 27, 2021 - and was in fact lifted at 12:01 am, April 27, 2021. ${ }^{13}$ What remains unknown, however, is how often Australian state governments will impose lockdowns and when the last one will occur. On one level, it is obvious that no governing power in any country can possibly predict with certainty when risk levels will decrease to a point it would consider wholly acceptable, whether that point is zero Covid cases or some unspecified minimum level of viral circulation. More profoundly, though, there can be no true end to the present state of emergency - nor did it genuinely begin with Covid-19 - because the danger that is to be minimized is posed by the population itself. There is no such thing as a risk level that the governing power would consider wholly acceptable, for the risk is precisely the circulation of the population - and that risk is always potentially unacceptable, since its potential unacceptability is the justification for the state's exercise of biopower. Biopower justifies itself, that is, by the implicit claim that the population must be subject to certain controls so that the danger it poses to itself will not become too great.

In other words, the reason it is unspecified how long the mechanisms of surveillance and control will remain in place is not only, and not fundamentally, because we are unable to calculate when the pandemic will end. It is because this surveillance is not, as we are often urged to believe, an exceptional response to an exceptional problem. It is crucial to understand the implications of the fact that the above quotation from Foucault does not refer to the Covid-19 pandemic, even though, as I observed, it seems to have been written for the present moment: these mechanisms that states have deployed did not emerge from nowhere but are inscribed within the existing operations of biopower, and so state responses to Covid-19 cannot be understood independently of broader considerations of state power. Recall here that the governing power works to preserve itself: the "security" that is at stake is, as the above quotation indicates, that "of the population and, consequently, of those who govern it." The population

13. See "Perth metro and Peel to enter a 3-day lockdown," WA.gov.au, April 23, 2021, https:// www.wa.gov.au/government/announcements/perth-metro-and-peel-enter-3-daylockdown, and "End of lockdown in Perth and Peel," WA.gov.au, April 26, 2021, https:// www.wa.gov.au/government/announcements/end-of-lockdown-perth-and-peel. 
must be constantly threatened so that power can operate to preserve itself. The constant operation of biopower works to protect the population from the threat that the population poses to itself; therefore the population is constantly threatened. To put it another way, biopower operates by first constituting the population as a threat in order to then protect it from that threat. Indeed, the population exists only as a threat: the population simply is that which for its own safety is subject to measurements, calculations, and controls that operate on the level of the group rather than of the individual. ${ }^{14}$ Without those measurements, calculations, and controls, a population would not be a population but would only be a group of individuals. And this analysis holds regardless of the motives or ultimate fate of any individual in the government. Once a system has been set in motion, one cannot escape that system simply by electing different people to sit at the top of it. Individual politicians may fall from grace when constituents object to the extent or manner of their exercise of their powers, but the biopolitical regime remains as long as there is a state that acts on the

14. Considering that the population itself is the threat, it is interesting to note that, while justifications for the mechanisms of control enforced during the Covid-19 pandemic tend to present their use as a matter of scientific necessity, the pandemic has often been described as a war. Announcing a countrywide lockdown, French president Emmanuel Macron repeatedly stated, "Nous sommes en guerre [We are at war]," and he called for a "mobilisation générale [general mobilization]" (Alexandre Lemarié and Cédric Pietralunga, " Nous sommes en guerre » : face au coronavirus, Emmanuel Macron sonne la "mobilisation générale »" Le Monde, March 17, 2020, https://www. lemonde.fr/politique/article/2020/03/17/nous-sommes-en-guerre-face-au-coronavirusemmanuel-macron-sonne-la-mobilisation-generale_6033338_823448.html). British prime minister Boris Johnson said that his government had taken "steps that are unprecedented since World War II" and said, "[W]e must act like any wartime government and do whatever it takes to support our economy" (Boris Johnson, "Prime Minister's statement on coronavirus (COVID-19): 17 March 2020," Gov.uk, March 17, 2020, https://www.gov.uk/government/speeches/pm-statement-on-coronavirus-17march-2020). American president Donald Trump said, "I view it as, in a sense, a wartime president" (Caitlyn Oprysko and Susannah Luthi, "Trump labels himself 'a wartime president' combating coronavirus," Politico, March 18, 2020, https://www.politico.com/ news/2020/03/18/trump-administration-self-swab-coronavirus-tests-135590). New York governor Andrew Cuomo said, "Ventilators are to this war what missiles were to World War II" ("'We Are All in Quarantine': 100\% of NY Work Force Must Stay Home, Cuomo Puts State on Pause," NBC New York, March 20, 2020, updated March 22, 2020, https://www.nbcnewyork.com/news/coronavirus/nyc-hospitals-weeks-from-runningout-of-supplies-as-death-toll-soars/2335762/"). And these are only a few examples. The language of war functions to conceal the biopolitical control of the population by casting us not as members of a population that is itself the threat but rather as soldiers fighting an external enemy. 
population. Even if all restrictions justified by the pandemic are eventually rolled back, the system within which they were instituted will still stand.

Indeed, techniques of control and surveillance have long been absorbing the Other into the abstraction of "the population" and teaching us to understand the population as a source of danger - while presenting themselves as obviously necessary measures. In the United States, one may think of the increased surveillance in airports following the terrorist attacks of September 11, 2001, which is not only an attempt to secure territory against a foreign enemy but which also functions to control the population and its circulation - though, again, surveillance long predates the Transportation Security Administration (TSA). As noted above, biopower aims to guarantee the health of the population: Foucault points out that in Europe public health has been an object of the police since the establishment of the modern state, and not only during epidemics; indeed, the entire organization of the city "will be ordered by, subordinated to principles, to concerns of health: the width of roads, the dispersion of elements that may produce miasmas and poison the atmosphere, butchers, abattoirs, cemeteries." ${ }^{15}$ The TSA certainly has vocal critics - though critiques often state that it is ineffective rather than questioning biopower itself - but it may seem obvious that cities should be designed in accord with "concerns of health." As also noted above, even critics of lockdowns may take for granted that the state should concern itself with the health of the population, while simply arguing that lockdowns fail to preserve the population's health or are actively detrimental to it. The apparent obviousness of the notion that the state should seek to ensure the health of the population is part and parcel of the functioning of biopower, which justifies itself by presenting its operations as natural. As Foucault explains later in his analysis, "the mechanism of security [...] connects to what the physiocrats called physical processes, which could be called natural processes, and which we could also call elements of reality." 16 Biopower operates because it ostensibly must: thus "the population as a collection of subjects is replaced by the population as a set of natural phenomena." 17 The idea that science prescribes the correct policy for governments to follow in responding to Covid-19 is, therefore, itself part of the system of biopower. Edward McGushin accurately summarizes

15. Foucault, STP (Fr), 332; STP (En), 325, translation modified.

16. Foucault, STP (Fr), 67; STP (En), 65-66, translation modified.

17. Foucault, STP (Fr), 360; STP (En), 352. 
the biopolitical pursuit of health when he writes that in the biopolitical state, "the social body is conceived very concretely as a medical body, and doctors are the ones who can heal. They have the task of outlining a politics of health." ${ }^{18}$ These sentences also could have been written about the Covid-19 pandemic - but they were not, and the fact that they were not reminds us that state responses to Covid-19 are not unusual responses to an unprecedented emergency but have arisen within and from the established systems of biopower. If it seems obvious that we should let experts determine public health policy, during the Covid-19 pandemic and in general, that is because we have already implicitly accepted the principle that the state should seek to promote the health of the population.

\section{How the Operations of Biopower Obscure the Face of the Other}

Having examined the operations of biopower in the context of the Covid-19 pandemic, I now return to Levinas to argue that, in defiance of Levinas's warning against imposing a narrative on the Other's suffering, the mechanisms of control that states have imposed coopt that suffering as a justification for the operations of biopower. I have already noted that biopower absorbs the Other into the population and that this is no accident but is essential to the functioning of biopower. Let us now consider more directly the biopolitical narrative about risk and suffering: whose suffering, exactly, does biopower operate to prevent? No one's, for biopower operates on the population, an abstract entity that is the object of statistical analysis and calculation. The claim that we must weigh the harm caused by Covid-19 against the harm caused by lockdowns and the risks posed by surveillance technologies and increased government control may at first appear easy to dismiss on the grounds that human life is infinitely valuable and not subject to calculation - which is a Levinasian point. Yet the endorsement of the control and surveillance of the population on the grounds that we must minimize Covid-19 deaths at all costs is equally a calculation from which the face of the Other is absent.

As I stated in the introduction to this article, my aim here is not to discuss the question of security versus freedom or to embark on a practical analysis of the likelihood that any particular state government will use the mechanisms of control and surveillance that it has put in place,

18. Edward McGushin, Foucault's Askēsis: An Introduction to the Philosophical Life (Evanston: Northwestern University Press, 2007), 227. 
such as contact tracing and cell phone tracking, for purposes other than responding directly to the Covid-19 pandemic. By challenging the discourse of security, by which these mechanisms are justified, on the grounds of ethics as understood by Levinas, I avoid the trap of criticizing that discourse in the name of a freedom that derives its sense only from the discourse of security itself. Foucault observes that "an apparatus of security, in any case the one I have spoken about, cannot operate well except on condition that it is given freedom, in the modern sense [the word] acquires in the eighteenth century: no longer the exemptions and privileges attached to a person, but the possibility of movement, change of place, and processes of circulation of both people and things." ${ }^{19}$ The point is not that circulation is irrelevant to freedom; rather, the point is that freedom comes to be defined strictly in relation to the apparatus of security. Freedom becomes that which the apparatus of security ostensibly secures: the governing power controls the circulation of the population so that the population may be free to circulate without harming itself. The question whether there should be fewer restrictions on circulation, or none at all, therefore readily transforms into the question of how many restrictions are needed to properly secure the circulation of the population. We then find ourselves debating, not the discourse of security itself, but rather a tradeoff that takes place entirely within the terms set by the discourse of security. For the discourse of security does not deny that circulation is a good. Even positing circulation as an absolute good still accepts the terms of the discourse of security in that it is a calculation about what is most beneficial for the population.

Levinasian ethics transcends the discourse of security, and the attendant debate over security versus freedom, because it responds to the Other rather than entering into calculations about the population. The operations of biopower and the discourse of security that justifies them inherently fail to recognize that, as Levinas puts it in "Useless Suffering," "the suffering in the other [...] is unforgiveable to me." ${ }^{20}$ What the control and surveillance that operate on the population obscure is precisely what Levinas calls "the recourse that people have to one another for help, before the astonishing alterity of the other has been banalized or dimmed down to a simple exchange of good manners [bons procédés] that has become

19. Foucault, STP (Fr), 50; STP (En), 48-49, brackets and bracketed words in original.

20. Levinas, ENE, 104; ENT, 94. 
established as an 'interpersonal commerce' of customs." ${ }^{21}$ For the mechanisms of security never operate on the Other at all - nor even on the self. My responsibility to recognize the Other's suffering as unforgiveable does not matter in biopolitics; neither does the Other's suffering or the Other's call to me. One cannot even say that the relation to the Other has become an "exchange of good manners" or "good processes," since in surveillance there is no relation to the Other. Through the operations of biopower, a faceless state controls a faceless population, ostensibly for the sake of the population and so for the sake of no person at all. ${ }^{22}$

The Other's suffering is thus co-opted for a narrative that justifies the mechanisms of security - that reinforces, that is, the power of the faceless state. Hence the Other's suffering is no longer recognized as senseless but is taken to mean that the centralizing power of the state must act to protect the population with which we identify ourselves - even though it is, in truth, a statistical abstraction to which we are wholly incidental. If the stories of the suffering Other did not reinforce the operations of biopower, they would be left untold or would be explained away. The Other's appeal to me is silenced, and my very responsibility is negated: both are irrelevant to the control and surveillance of the population, and so the surveillance does not see them and the control disregards them. But that which cannot be surveilled and controlled has no reality, as far as biopower is concerned. Reality is summed up in the population and the danger it poses to itself and if it were not the Covid-19 virus it would be something else since, as explained in the previous section, the population is inherently a threat. Whether or not there is a literal epidemic occuring, there is always some contagion by which surveillance can justify itself, for the population itself is the contagion. We are not soldiers in a war against Covid-19, far from it: as far as the operations of biopower are concerned, we ourselves are Covid-19. The face of the Other is transformed into an abstract carrier of

21. Levinas, ENE, 111; ENT, 101, translation modified.

22. Mask requirements are particularly interesting in light of this obscuring of the face of the Other. It is true that ethical recognition of the Other does not depend on seeing his or her literal face. To take an example that is unrelated to the current discussions of Covid-19, one skier may recognize another as the Other even if both are concealing their faces against the cold. Yet the discourse of security within which the mask requirement finds its sense does obscure the Other's face in the Levinasian sense of the word. The mask, as one of the mechanisms by which the governing power controls the population, does stand for a discourse that places itself between self and Other in order to conceal them both. 
the virus, much as, in the case of post-9/11 airport security in the United States, the face is transformed into an abstract potential terrorist. ${ }^{23}$

To fully grasp the relevance of "Useless Suffering" to this discussion of biopower, it is crucial to understand that theodicy ultimately serves less to justify God than to justify ourselves. The notion that others' suffering is ultimately meaningful, states Levinas, "is the grand idea necessary to the inner peace of souls in our distressed world." 24 When we claim to have proven that God is not responsible for evil because evil is part of some grand plan and therefore, in the final analysis, serves the good, we are really saying that we ourselves are innocent: we did not need to intervene because the grand plan ensures that the evil and our own inaction will work out for good. Levinas's rejection of theodicy does not blame God for evil and suffering; it blames us and commands us to fight them. The discourse of security functions, however, as a theodicy without God: it tells us that human suffering is subject to calculation and that we ourselves are not responsible for it as long as we do what we are told the calculations command. Whatever suffering still occurs is the fault of those who refused to obey the calculations, or else it is acceptable, according to those same calculations. And, as noted, that suffering serves to justify the orders we are given on the basis of the calculations. Suffering, then, takes on various meanings: it is the price we must pay to ensure that certain other interests are met (thus harm from Covid-19 and harm from lockdowns are traded against each other), it is a sign that some are disobeying orders and must therefore be punished, and, above all, it is a sign that we must submit to the governing power that knows better than we do how to calculate what degrees of suffering and what sources of suffering are acceptable.

It is true that an individual person may well submit to contact tracing, download a tracking app, and obey lockdown restrictions out of a sincere desire to care for the Other. As we have already seen, however, the functioning of biopower, in its various manifestations, does not depend on individual motivations. One might ask whether this independence from individual motives is not a good thing: may it not be the case that, at least

23. Certainly not everyone is perceived as a threat, or as worthy of protection, to the same degree, but ending discrimination in the operations of biopower would not lead to every person being recognized as the Other to whom I am responsible, since those operations do not and cannot acknowledge the Other at all. Note that it is not that the individuals within a system view every person whom they encounter as a threat; a TSA agent may, for instance, encounter nobody whom she consciously or unconsciously fears is a terrorist. The point is that the system itself constitutes each person as a threat.

24. Levinas, ENE, 106; ENT, 96. 
in some instances, biopower forces people to act for the good of the Other whether they want to or not, and then may biopower not serve the Other? This question utterly misunderstands biopower, however. If on some occasion biopower operates in a way that is, on balance, genuinely good for people, that is a coincidence. Indeed, the person who accepts control and surveillance because she wishes to serve the Other does so in spite of the principles by which the mechanisms of control and surveillance operates. This is so because biopower interposes the governing power between the self and the Other. Moreover, in justifying itself by presenting itself as natural, biopower further excludes the ethical, which is more fundamental than the really or apparently natural. As Levinas states in "Humanism and An-Archy," my responsibility to the Other is an-archic because it is "prior to Being and beings, not saying itself in ontological categories." 25 The legitimacy of the biopolitical depends on a denial of this an-archy. For biopower takes itself as the arché, the origin or first principle. It cannot be conditioned by ethics because it acts only on the population and cannot hear the call of the Other.

\section{Conclusion: Risking a Just Politics}

We cannot in practice exist purely within the ethical realm; we must, though it is strictly speaking impossible, calculate and compare the interests of the Other and the third. ${ }^{26}$ It remains, however, that the biopolitical state is not the just state of which Levinas does speak favorably. In

25. Emmanuel Levinas, Humanisme de l'autre homme (Paris: Fata Morgana, 1987), 91; Humanism of the Other, trans. Nidra Poller (Chicago: University of Illinois Press, 2003), 57.

26. Recall Levinas's statement that "it is always starting out from the Face, from the responsibility for the other that justice appears, which calls for judgment and comparison, a comparison of what is in principle incomparable, for every being is unique; every other is unique" (ENE, 114; ENT, 104). And as he writes elsewhere, "The third party is other than the neighbor, but also another neighbor, and also a neighbor of the other, and not simply his fellow. [...] Justice is necessary, that is, comparison, coexistence, contemporaneousness, assembling, order, thematization, the visibility of faces, and thus intentionality and the intellect, and in intentionality and the intellect, the intelligibility of a system, and thence also a copresence on an equal footing as before a court of justice" (Emmanuel Levinas, Autrement qu'être ou au-delà de l'essence [Paris: Kluwer Academic, 2011], 245; Otherwise than Being or Beyond Essence, trans. Alphonso Lingis [Pittsburgh: Duquesne University Press, 2006], 157). The third party is also an Other, and so I am responsible to and for both the Other and the third - yet their interests may conflict, or one may act with violence against the other, and so their respective claims must be weighted and compared. Doing so is the task of justice. 
"Philosophy, Justice, and Love," for instance, he writes that "there is a possible harmony between ethics and the state. The just state will come from just men and women and saints rather than from propaganda and preaching." ${ }^{27}$ Nor will it come from the operations of biopower - since biopower has no place for "just men and women and saints" but only for the abstract population. Rather, working out how humans may live in a just community is the project of a lifetime for all of us: justice will come only through each one of us striving to be just. And it is much easier to say what justice is not than to say what it is; how could it be otherwise if justice is not to forget the an-archic call of the Other that precedes every supposedly first principle? Because justice must always be referred to the call that exceeds my comprehension, it cannot be set forth in a program.

A key problem resulting from the operations of biopower is, unsurprisingly, a crisis of trust: the more natural it seems to submit to control and surveillance by a centralized state that exists to secure the population against threats, the easier it becomes to see each other person as an incarnation of the threat that is the population, and the harder dialogue becomes. Ernst Wolff warns that because Levinasian ethics is an-archic and therefore cannot tell us exactly how justice is to be lived out, a Levinasian politics "carries in it the danger of being a politics of the war of every citizen's notion of justice against that of the others." 28 The only way to avoid intractable conflict between different conceptions of justice is precisely dialogue among those who are committed to seeking justice but the more we see each other as a threat, the less we are willing to trust that others are indeed committed to seeking justice. The path toward this necessary dialogue must involve a radical questioning of the operations of biopower that separate us from each other by absorbing us into the abstraction of the population.

Crucially, this radical questioning demands that we risk error. For although justice must calculate, no calculations tell us what justice is. Madeleine Fagan rightly points out that there is never, for Levinas, a purely ethical relation of only self and Other into which the third then enters; we are always already within the political. She concludes that "the consequences of approaching Levinas's thought as refusing to provide a pure vision of ethics or responsibility, of foregrounding his argument that

27. Levinas, ENE, 131; ENT, 120.

28. Ernst Wolff, “The Quest for Justice versus the Rights of the Other?” Sofia Philosophical Review 3, no. 2 (2009): 78. 
the Third is present even in the face of the Other in the face-to-face mean that Levinas cannot be used to provide an ethical ground, so returning us once again to the risk and uncertainty which may allow for responsibility." ${ }^{29}$ Indeed. To be responsible is to bear the risk of uncertainty and error. From the perspective of ethics, a great lie of biopower is its promise to secure the population against error through calculations that tell us what risks to run and how much risk is acceptable, thereby freeing us not only from responsibility for the Other's suffering but also from responsibility for judging the interests of the Other and the third. Controlled, we are responsible for nothing: we do not ourselves bear the weight of the difficult and uncertain quest for justice, for judging different interests is not our task but that of the biopolitical state. Questioning the operations of biopower means, therefore, questioning the very notions of securing the population and reducing risk. Where this questioning may lead us is necessarily uncertain. If we wish to live in a just community, however, we must embark on this questioning of biopower and of its promise of security - and we must do so even and especially in a time of pandemic when it is all too easy to accept the operations of biopower as natural.

\section{References}

"End of lockdown in Perth and Peel." WA.gov.au. April 26, 2021. https://www.wa.gov.au/ government/announcements/end-of-lockdown-perth-and-peel.

Fagan, Madeleine. "The inseparability of ethics and politics: Rethinking the third in Emmanuel Levinas." Contemporary Political Theory 8, no. 1 (2009): 5-22.

Foucault, Michel. "La politique de la santé au XVIII' siècle." In Dits et écrits, 1954-1988, vol. 3, 1976-1979, edited by Daniel Defert and François Ewald with Jacques Lagrange, 13-27. Paris: Gallimard, 1994. ["The Politics of Health in the Eighteenth Century." Translated by Robert Hurley. In The Essential Works of Foucault, 1954-1988, vol. 3, Power, edited by James D. Faubion, 90-105. New York: The New Press, 2001.]

Foucault, Michel. Sécurité, territoire, population: Cours au Collège de France, 1977-1978. Paris: Seuil/Gallimard, 2004. [Security, Territory, Population: Lectures at the Collège de France, 19771978. Translated by Graham Burchell. New York: Palgrave Macmillan, 2007.]

Johnson, Boris. "Prime Minister's statement on coronavirus (COVID-19): 17 March 2020." Gov.uk. March 17, 2020. https://www.gov.uk/government/speeches/pm-statement-on-coronavirus-17march-2020.

Landler, Mark, and Stephen Castle. "Behind the Virus Report that Jarred the U.S. and the U.K. to Action." The New York Times. March 17, 2020. Updated April 2, 2020. https://www.nytimes. com/2020/03/17/world/europe/coronavirus-imperial-college-johnson.html.

Lemarié, Alexandre, and Cédric Pietralunga. "« Nous sommes en guerre » : face au coronavirus, Emmanuel Macron sonne la « mobilisation générale »." Le Monde. March 17, 2020. https:// www.lemonde.fr/politique/article/2020/03/17/nous-sommes-en-guerre-face-au-coronavirus-

29. Madeleine Fagan, "The inseparability of ethics and politics: Rethinking the third in Emmanuel Levinas," Contemporary Political Theory 8, no. 1 (2009), 21. 
emmanuel-macron-sonne-la-mobilisation-generale_6033338_823448.html.

Levinas, Emmanuel. Autrement qu'être ou au-delà de l'essence. Paris: Kluwer Academic, 2011. First published 1978. [Otherwise than Being or Beyond Essence. Translated by Alphonso Lingis. Pittsburgh: Duquesne University Press, 2006. First published 1991.]

Levinas, Emmanuel. Entre nous: Essais surle penser-à-l'autre. Paris: Grasset, 1993. First published 1991. [Entre Nous: On Thinking-of-the-Other. Translated by Michael B. Smith and Barbara Harshav. New York: Columbia University Press, 1998.]

Levinas, Emmanuel. Humanisme de l'autre homme. Paris: Fata Morgana, 1987. First published 1972. [Humanism of the Other. Translated by Nidra Poller. Chicago: University of Illinois Press, 2003.]

McGushin, Edward. Foucault's Askēsis: An Introduction to the Philosophical Life. Evanston: Northwestern University Press, 2007.

Oprysko, Caitlyn, and Susannah Luthi."Trump labels himself 'a wartime president' combating coronavirus." Politico. March 18, 2020. https://www.politico.com/news/2020/03/18/trumpadministration-self-swab-coronavirus-tests-135590.

"Perth metro and Peel to enter a 3-day lockdown." WA.gov.au. April 23, 2021. https://www.wa.gov. $\mathrm{au} /$ government/announcements/perth-metro-and-peel-enter-3-day-lockdown.

Redden, Elizabeth. "Government Rescinds International Student Policy." Inside Higher Ed. July 15, 2020. https://www.insidehighered.com/news/2020/07/15/trump-administration-dropsdirective-international-students-and-online-courses.

Teri Schulz, "Do Sweden's COVID liberties cost lives?" Deutsche Welle, April 21, 2021, https://www. dw.com/en/do-swedens-covid-liberties-cost-lives/a-57268022.

“We Are All in Quarantine': 100\% of NY Work Force Must Stay Home, Cuomo Puts State on Pause." NBC New York. March 20, 2020. Updated March 22, 2020. https://www.nbcnewyork. $\mathrm{com} /$ news/coronavirus/nyc-hospitals-weeks-from-running-out-of-supplies-as-death-tollsoars $/ 2335762 /$.

Wolff, Ernst. "The Quest for Justice versus the Rights of the Other?" Sofia Philosophical Review 3, no. 2 (2009): 69-78. 